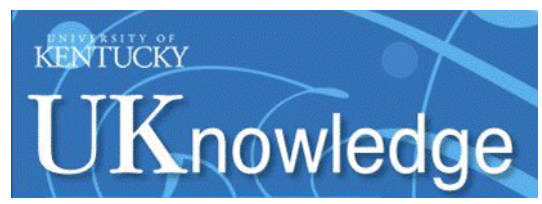

University of Kentucky

UKnowledge

\title{
Healthcare Contact and Treatment Uptake Following Hepatitis C Virus Screening and Counseling Among Rural Appalachian People Who Use Drugs
}

Dustin B. Stephens

University of Kentucky, dbst222@uky.edu

April M. Young

University of Kentucky, april.young@uky.edu

Jennifer R. Havens

University of Kentucky, jennifer.havens@uky.edu

Follow this and additional works at: https://uknowledge.uky.edu/behavsci_facpub

Part of the Behavior and Behavior Mechanisms Commons, Community Health and Preventive

Medicine Commons, Health Services Research Commons, and the Substance Abuse and Addiction

Commons

Right click to open a feedback form in a new tab to let us know how this document benefits you.

\section{Repository Citation}

Stephens, Dustin B.; Young, April M.; and Havens, Jennifer R., "Healthcare Contact and Treatment Uptake Following Hepatitis C Virus Screening and Counseling Among Rural Appalachian People Who Use Drugs" (2017). Behavioral Science Faculty Publications. 42.

https://uknowledge.uky.edu/behavsci_facpub/42

This Article is brought to you for free and open access by the Behavioral Science at UKnowledge. It has been accepted for inclusion in Behavioral Science Faculty Publications by an authorized administrator of UKnowledge. For more information, please contact UKnowledge@lsv.uky.edu. 


\section{Healthcare Contact and Treatment Uptake Following Hepatitis C Virus Screening and Counseling Among Rural Appalachian People Who Use Drugs}

Digital Object Identifier (DOI)

https://doi.org/10.1016/j.drugpo.2017.05.045

Notes/Citation Information

Published in International Journal of Drug Policy, v. 47, p. 86-94.

(c) 2017 Elsevier B.V. All rights reserved.

This manuscript version is made available under the CC-BY-NC-ND 4.0 license https://creativecommons.org/licenses/by-nc-nd/4.0/.

The document available for download is the author's post-peer-review final draft of the article. 


\title{
Healthcare contact and treatment uptake following hepatitis C virus screening and counseling among rural Appalachian people who use drugs
}

\author{
Dustin B. Stephens $^{a, 2}$, April M. Young ${ }^{b, c}$, and Jennifer R. Havens ${ }^{c}$ \\ aUniversity of Kentucky College of Medicine, Department of Behavioral Science, 845 Angliana \\ Ave., Lexington, KY USA 40508, dbst222@g.uky.edu \\ bUniversity of Kentucky College of Public Health, Department of Epidemiology, 111 Washington \\ Avenue, Office 211C, Lexington, KY USA 40536, april.young@uky.edu \\ 'University of Kentucky College of Medicine, Department of Behavioral Science, Center on Drug \\ and Alcohol Research, 845 Angliana Ave., Lexington, KY USA 40508, jhave2@uky.edu
}

\begin{abstract}
Background-Hepatitis $\mathrm{C}$ virus (HCV) remains a major contributor to morbidity and mortality worldwide. Since 2009, Kentucky has led the United States in cases of acute HCV, driven largely by injection drug use in rural areas. Improved treatment regimens hold promise of mitigating the impact and transmission of $\mathrm{HCV}$, but numerous barriers obstruct people who inject drugs (PWID) from receiving care, particularly in medically underserved settings.

Methods-503 rural people who use drugs were recruited using respondent-driven sampling and received HCV screening and post-test counseling. Presence of HCV antibodies was assessed using enzyme immunoassay of dried blood samples. Sociodemographic and behavioral data were collected using computer-based questionnaires. Predictors of contacting a healthcare provider for follow-up following $\mathrm{HCV}$-positive serotest and counseling were determined using discrete-time survival analysis.
\end{abstract}

Results-150 (59\%) of 254 participants reported contacting a healthcare provider within 18 months of positive serotest and counseling; the highest probability occurred within six months of serotesting. 35 participants (14\%) reported they were seeking treatment, and $21(8 \%)$ reported receiving treatment. In multivariate time-dependent modeling, health insurance, internet access, prior substance use treatment, meeting DSM-IV criteria for generalized anxiety disorder, and recent marijuana use increased the odds of making contact for follow-up. Participants meeting

çorresponding author: Dustin B. Stephens, dbst222@g.uky.edu.

2 current mailing address: Dustin B. Stephens, 953 W. $7^{\text {th }}$ Street, San Pedro, CA 90731

Publisher's Disclaimer: This is a PDF file of an unedited manuscript that has been accepted for publication. As a service to our customers we are providing this early version of the manuscript. The manuscript will undergo copyediting, typesetting, and review of the resulting proof before it is published in its final citable form. Please note that during the production process errors may be discovered which could affect the content, and all legal disclaimers that apply to the journal pertain.

Declaration of Interest / Conflict of Interest Statement:

The authors have no financial conflicts of interest to disclose. 
criteria for major depressive disorder and reporting prior methadone use, whether legal or illegal, were less likely to contact a provider.

Conclusion-While only $8 \%$ received treatment after $\mathrm{HCV}$-positive screening, contacting a healthcare provider was frequent in this sample of rural PWID, suggesting that the major barriers to care are likely further downstream. These findings offer insight into the determinants of engaging the cascade of medical treatment for $\mathrm{HCV}$ and ultimately, treatment-as-prevention. Further study and increased resources to support integrated interventions with effectiveness in other settings are recommended to mitigate the impact of $\mathrm{HCV}$ in this resource-deprived setting.

\section{Keywords}

Hepatitis C; drug injection; treatment; rural

\section{Introduction}

Hepatitis $\mathrm{C}$ virus (HCV) remains a major public health problem worldwide, causing over 500,000 deaths per year (Lim et al., 2012) and greater mortality in the United States than that attributed to HIV (Ly et al., 2012). The virus is hyper-endemic worldwide among people who inject drugs (PWID), with $73 \%$ median seroprevalence among individuals who have ever injected and transmission typically occurring via sharing of needles, syringes, and drugpreparation equipment (Nelson et al., 2011). Unfortunately, medical evaluation to assess for disease progression and treatment eligibility occurs sporadically among seropositive individuals in the general population (Spradling et al., 2014) and even less frequently among PWID (Wiessing et al., 2014). Fortunately, remarkable advances in pharmacotherapy now offer greater than $90 \%$ efficacy for most genotypes, tremendously decreased adverse effect profiles, and shortened interferon- and ribavirin-free regimens (Li \& De Clercq, 2017; Rehermann, 2016), and it has been shown that PWID in community clinics and opioid substitution programs can achieve rates of sustained virologic response (SVR) equivalent to non-injectors even with older regimens including interferon and ribavirin (Grebely et al., 2016; Grebely et al., 2015). For these reasons, identifying factors associated with seeking and receiving HCV-related medical care after seropositive test and post-test risk-reduction counseling $(\mathrm{T} \& \mathrm{C})$ is critical in underserved and often stigmatized populations such as PWID (Grebely et al., 2008).

In prior research, PWID-specific barriers to HCV-related medical care have included lack of status awareness and HCV-related knowledge, homelessness and unstable lifestyle, lack of social support, psychiatric comorbidity, HIV co-infection, fear of diagnosis and medical procedures, concerns regarding drug toxicity and low efficacy, and lack of transportation (Mravcik et al., 2013). Stoove et al. (2005) reported that patients with no history of IDU were greater than threefold more likely to be referred to an HCV specialist than PWID, and current injectors were significantly less likely to initiate treatment, underlining substantial impact of IDU status on HCV-related care (Stoove, Gifford, \& Dore, 2005). Similarly, despite $81 \%$ being interested in receiving treatment, just $27 \%$ of PWID in three U.S. cities received medical evaluation HCV-positive serotesting (Strathdee et al., 2005). In another study of urban PWID, just 14\% and 6\% reported receiving medical evaluation for HCV and initiating treatment, respectively; barriers to treatment included perceptions of severe 
adverse effects, low efficacy, and deprioritization due to lack of symptoms (Mehta et al., 2008). Grebely et al. (2009) found only 15 of 1360 seropositive Canadian PWID had initiated treatment, among whom only four completed treatment and three achieved sustained virologic response. Strikingly, HCV seroconversion occurred at 25 times the rate of HCV treatment (Grebely et al., 2009). However, when referral to medical care was coupled with seropositive T\&C, medical evaluation occurred in 76\% of PWID, and guideline-based clinical criteria became the major determinant of treatment initiation (Grebely et al., 2010). Finally, of particular relevance to rural PWID, shorter travel distance to clinics (Monnet et al., 2008) and increasing community size (Astell-Burt, Flowerdew, Boyle, \& Dillon, 2011) have been positively associated with HCV-related medical care.

Identifying predictors of both seeking and engaging in $\mathrm{HCV}$-related medical care after $\mathrm{T} \& \mathrm{C}$ is central to enhancing public health interventions among PWID, especially with regard to the utility of HCV "treatment as prevention" (Grebely \& Dore, 2014; Martin et al., 2013). Such efforts are particularly relevant in medically underserved rural areas such as the Central Appalachian region of the United States, where harm reduction, substance use disorder (SUD), and integrated treatment programs recommended to address widespread HCV among PWID (Birkhead et al., 2007; Grebely et al., 2010) are largely unavailable (Appalachian Regional Commission, 2008; Des Jarlais et al., 2015; Stensland J, 2002). Although a March 2015 Kentucky law permitted syringe exchange programs (SEPs) and expanded access to naloxone and other harm reduction services, as of February 2017 only 8 of 54 Appalachian Kentucky counties had established operational SEPs (Department for Public Health, 2015). PWID also encounter barriers to accessing syringes in local pharmacies, as Kentucky law requires that persons engaged in sales of syringes collect detailed information about individuals purchasing syringes, including information on the planned use of such syringes (Kentucky Legislative Research Commission, 2005). By contrast, such programs are often more accessible to PWID in major urban areas and/or in countries with comprehensive $\mathrm{HCV}$ public health programs, where the majority of prior research on HCV-related healthcare engagement among PWID has occurred.

As yet there is no clear consensus regarding factors likely to increase seeking and engagement in HCV-related care, and previously reported characteristics may be highly population- and context-specific. Moreover, little is known regarding rural PWID, who may differ significantly from their urban and suburban counterparts (Havens et al., 2013) and are thought to be in large part driving surging resurgent HCV incidence observed in the United States in recent years (Zibbell et al., 2015). In the United States, Kentucky has reported the highest incidence of acute HCV since 2009 (Centers for Disease Control and Prevention, 2016). For these reasons, this study identifies predictors of contacting a healthcare provider for recommended follow-up and describes the uptake of treatment following HCVseropositive $\mathrm{T} \& \mathrm{C}$ in a medically underserved population of people who use and inject drugs in rural Appalachian Kentucky. 


\section{Methods}

\section{Design and sampling}

Data were collected during the cohort study Social Networks among Appalachian People with an overall aim of identifying risk factors for transmission of infectious diseases including HCV, HIV, and herpes simplex virus type 2 among people who use drugs in the rural Central Appalachian region of eastern Kentucky, USA. As described previously (Havens et al., 2013), 503 participants were recruited from November 2008 to August 2010 using respondent-driven sampling (RDS) (Heckathorn, 1997), with data collected during the 18-month wave until February 2012. Eligible participants were 18 years or older, community-dwelling, and had used heroin, crack/cocaine, methamphetamine, prescription opioids non-medically within the last six months. Participants with a positive HCV serum antibody test at study enrollment, six-month, or twelve-month follow-up and receiving test results and counseling at least 30 days prior to subsequent interviewing were included in this analysis. All participants gave informed consent and were compensated \$50 USD for each study visit. Study procedures were approved by the University of Kentucky Institutional Review Board, and a Certificate of Confidentiality was obtained from NIH.

\section{Data collection}

HCV screening was completed at each study visit using the Home Access® Hepatitis C Check serum antibody test with standard pre-test counseling given to all participants. This test utilizes dried blood spot specimens obtained by finger-stick and third-generation enzyme immunoassay to detect HCV serum antibodies; sensitivity and specificity are $98.2 \%$ and 99.6\%, respectively (US Food and Drug Administration, 1999). Post-test counseling was tailored to test results with standard messages including advising seropositive participants to seek medical evaluation for $\mathrm{HCV}$ from a healthcare provider and avoid alcohol intake as recommended by CDC (Centers for Disease Control and Prevention, 1998; Smith et al., 2012), and to refrain from sharing syringes and other IDU-related equipment (AASLDIDSA, 2016), along with information regarding local options to obtain appropriate follow-up medical care.

The primary outcome variable was self-reported contact of a healthcare provider for medical follow-up receipt of seropositive $\mathrm{T} \& \mathrm{C}$ during the study, assessed via the following question: "After testing positive for hepatitis $C$ did you contact a health professional to obtain followup testing?"Self-reported seeking and receiving treatment for HCV was also collected, with the following questions for the former item: "Did you seek treatment for hepatitis C?" Sociodemographic and behavioral data were collected via interviewer-administered questionnaires using computer-assisting personal interviewing software, as described elsewhere (Havens et al., 2013), along with participant responses to the MINI neuropsychiatric interview version 5.0.31 (Sheehan et al., 1998), assessing for symptoms of major depressive disorder (MDD), generalized anxiety disorder (GAD), post-traumatic stress disorder, and antisocial personality disorder utilizing Diagnostic and Statistical Manual of Mental Disorders, 4th Edition (DSM-IV-TR) criteria. Lifetime and past sixmonth illicit and non-medical prescription drug use was asked at each interview, along with 
recent and lifetime alcohol and legal methadone and buprenorphine use, SUD treatment, drug overdose, and incarceration.

Shortest driving distance from participant address to Appalachian Regional Health Center (Hazard, KY), an inpatient and outpatient facility offering specialist HCV care centrally location to the five rural counties ( $>90 \%$ from Perry County, KY) sampled in this study and identified in post-test counseling materials provided to participants, was calculated at each visit using geocoded North American Street Map data (Environmental Systems Research Institute, 2010) and the Network Analyst tool in ArcGIS, version 10.2 (Redlands, CA). Participants who moved from the area after recruitment $(n=10)$ were excluded from analysis of this measure. Possession of a driver's license and access to a vehicle was asked at study enrollment to assess availability of transportation. HCV knowledge was assessed using six true/false questions including awareness of HCV treatment, as was knowledge of HCVpositive status prior to study enrollment. Finally, number of individuals in each participant's social support network was calculated from social network data at each interview, as described elsewhere (Young, Jonas, \& Havens, 2013). Participants reported "alters" from whom they received social support in the form of food, money, or emotional assistance; the total number of "alters" named as providers of social support is hereafter referred to as "social support network out-degree" and was calculated for each study visit.

\section{Statistical analysis}

Longitudinal bivariate odds ratios were calculated in discrete time, controlling for the main effect of time and adjusted with sampling weights to correct for potential bias introduced by non-random sampling using RDSAT version 7.1 (Ithaca, NY) (Heckathorn, 1997; Volz et al., 2012). Time-varying measures were lagged by one study interval, with independent variables significant at $p<0.10$ considered for inclusion in a multivariate model. Sociodemographic measures (sex, race, age, education, and income) were considered for inclusion in the multivariate model and retained in the final model if inclusion impacted other independent measures by $\geq 10 \%$ (Hosmer \& Lemeshow, 1989). The following previously reported factors impacting access to HCV care in PWID were also considered in the final model: HCV-positive serostatus awareness, IDU or SUD treatment within the past six months, opioid substitution therapy (OST) reported as legally prescribed use of either methadone or buprenorphine, and the DSM-IV psychiatric measures described above.

Bivariate and multivariate analyses were conducted using discrete-time survival analysis (DTSA) (Allison, 1982; Singer \& Willett, 1993, 2003), which utilizes a discrete-time hazard function depicting a set of probabilities observed during each time interval for intervalcensored dependent measures (Singer \& Willett, 1993). For this analysis, more parsimonious approximations of the main effect of time (constant and linear approximations) were compared to the discrete-time model in a hierarchical manner utilizing goodness-of-fit testing $p<0.05$ level of significance. Nested parameterizations for time not differing significantly from the discrete model were considered, and independent measures were assessed using a hierarchical forward-selection process utilizing maximum-likelihood-based Wald testing with a chi-squared distribution and significance level of $p<0.05$ for potential covariates and the Bayesian information criterion (BIC) to differentiate between candidate 
models. As DTSA assumes proportional odds across time for each predictor (Singer \& Willett, 2003), independent measures in the final model were assessed for interactions with time at $p<0.05$ level of significance.

\section{Results}

$\mathrm{N}=254$ of 503 baseline sample $(50.5 \%)$ received HCV-seropositive T\&C at enrollment $\left(\mathrm{n}_{0}=226\right)$, six months $\left(\mathrm{n}_{6}=21\right)$, and twelve months $\left(\mathrm{n}_{12}=8\right)$; one participant not returning for interviewing following initial study visit was excluded. Table 1 summarizes sample proportions and RDS-adjusted population estimates of HCV-related healthcare events reported at any study visit. 150 participants $(59.1 \%)$ reported contacting a healthcare provider for follow-up after receiving positive $\mathrm{T} \& \mathrm{C}$, representing an estimated $51.8 \%$ of the sampled population. Of these 150 individuals, $35(13.8 \%)$ described themselves as seeking treatment (12.4\% population estimate), and 21 ( $8.3 \%$ of sample; $7.8 \%$ population estimate) reported receiving treatment for $\mathrm{HCV} .31$ participants were lost to follow-up, and the average number of follow-up visits for the sample was 1.9. Although the data describing where participants sought treatment were incomplete, most reported receiving follow-up testing and/or treatment through primary care providers, followed by community health centers (data not shown).

As summarized in Table 2, study participants were predominantly male (60\%), white (95\%), and single (76\%), with a mean age of 33 years. $95 \%$ reported lifetime history of IDU, and 98\% reported ever having used OxyContin ${ }^{\circledR}$ non-medically, whereas $94 \%$ and $95 \%$ reported use of sedatives and cocaine, respectively. $87 \%$ had been incarcerated, and $28 \%$ reported history of drug overdose. 80 participants (32\%) reported having any form of health insurance and $42(17 \%)$ received SUD treatment during data collection; of note, there were no HIV-positive participants through twelve-month screening. Bivariate estimates of association with contacting a healthcare provider are summarized in table 2 .

Table $3 \mathrm{a}$ depicts the conditional probability of contacting a healthcare provider after $\mathrm{T} \& \mathrm{C}$ : hazard was greatest in the six months immediately following HCV-positive T\&C (0.38), with uniformly lower values after twelve (0.23) and eighteen months (0.23). As shown in table $3 b$, RDS-adjusted population estimates for probability of contacting a provider for follow-up decreased after the six-month study visit (0.37) to lower values at 12-month (0.18) and 18-month (0.16) study visits. The linear model for the main effect of time was selected for final multivariate modeling as it did not differ significantly from the fully discrete model $(p=0.68)$. Hazard functions for the fully discrete model and linear time approximation are depicted in Figure 1.

The final multivariate model with independent predictors of contacting a provider for follow-up is presented in Table 4. No significant interactions with time were detected among independent covariates, supporting the proportional odds assumption. The main effect of time independently predicted $40 \%$ decreased odds of contacting a provider for each 6-month study interval elapsed since $\mathrm{T} \& \mathrm{C}$ (adjusted $\mathrm{OR}[\mathrm{aOR}]=0.6$ ). Having any form of health insurance more than doubled the odds of contacting a provider during the respective study interval ( $\mathrm{aOR}=2.1)$, and meeting criteria for generalized anxiety disorder exhibited a similar 
strong positive association ( $\mathrm{aOR}=2.6)$. By contrast, meeting criteria for major depressive disorder halved the odds of contacting a provider $(\mathrm{aOR}=0.5)$, and two methadone-related measures decreased the odds of contacting a provider: recent legal use $(\mathrm{aOR}=0.2)$ and lifetime illegal use $(\mathrm{aOR}=0.3)$. By contrast, recent marijuana use was associated with increased odds of making contact for medical follow-up $(\mathrm{aOR}=1.7)$. Finally, awareness of prior HCV-positive testing did not significantly increase odds of the primary outcome ( $\mathrm{aOR}=1.7 ; \mathrm{p}<0.10)$ but was retained in the model given improved goodness-of-fit suggested by BIC relative to the reduced model.

\section{Discussion}

In this study of predictors of HCV-related medical care-seeking and treatment uptake, nearly $60 \%$ of rural participants who use drugs contacted a healthcare provider for follow-up evaluation as recommended after seropositive T\&C. Proportions of participants reporting they sought $(<15 \%)$ and received treatment $(<10 \%)$ were markedly lower. Other studies of PWID sampled from cities in the United States have reported markedly lower proportions of individuals undergoing medical evaluation following $\mathrm{HCV}+$ serotesting, typically in the range of 21\% (Mehta et al., 2008) to 27\% (Strathdee et al., 2005), although few researchers have specifically examined the initial step of medical follow-up (i.e., contacting a healthcare provider to make an appointment). These proportions contrast with studies of HCVseropositive individuals receiving medical evaluation in other settings: for instance, $75 \%$ of Australian PWID receiving OST (Treloar, Hull, Dore, \& Grebely, 2012) and 57\% of a U.S. clinic-based sample (Spradling et al., 2014). Another study of 245 seropositive patients from the New York City health department reported that $67 \%$ obtained RNA testing when referred directly to medical services after T\&C (McGibbon, Bornschlegel, \& Balter, 2013), whereas $53 \%$ of PWID received medical evaluation in data reported by Grebely and colleagues (2010) when healthcare referral was offered reflexively after T\&C. In the latter study, clinical criteria based on published guidelines emerged as the primary determinant of $\mathrm{HCV}$ treatment initiation (Grebely et al., 2010).

While the proportion making contact to arrange medical follow-up for HCV in this rural sample was relatively high, the proportion describing themselves as seeking treatment in particular lagged in comparison. However, the $8 \%$ ultimately receiving treatment is comparable to other studies, which have typically ranged from 3\% to $10 \%$ (Cullen, Stanley, Langton, Kelly, \& Bury, 2007; Mehta et al., 2008; Trepka et al., 2007) and higher uptake reported in community clinic-based (Morrill, Shrestha, \& Grant, 2005) and Australian (Grebely et al., 2008) studies. In this sample, an impressive 21 of 35 (60\%) participants who reported that they sought treatment from a healthcare provider ended up receiving treatment for HCV. This might suggest that individual-level barriers overshadow those at the physician level, given that although many participants made the initial step of contacting a provider for HCV-related follow-up, relatively few described themselves as seeking treatment through the encounter. This could also perhaps reflect the reputation of severe side effects and middling efficacy among the older interferon-based treatments available at the time data were collected. 
As in prior research (Denniston, Klevens, McQuillan, \& Jiles, 2012; Stepanova, Kanwal, ElSerag, \& Younossi, 2011), health insurance coverage was a robust predictor of making contact for medical follow-up in this rural sample. Unfortunately, however, nearly $70 \%$ of the cohort was uninsured throughout the study period, implicating lack of insurance coverage and most likely, healthcare costs as major barriers to $\mathrm{HCV}$ care among rural Appalachians who use drugs. However, given the recent, but uncertain expansion of health insurance coverage in the United States (Gallup Well-Being, 2014; U.S. Department of Health and Human Services, 2014) and in Kentucky in particular (Brammer, 2014), coupled with rapidly evolving cost and efficacy of HCV pharmacotherapy, further study of this perennially volatile factor among rural PWID is needed.

Concordant with other research reporting correlation between interest in IDU cessation and HCV treatment (Strathdee et al., 2005), lifetime history of SUD treatment increased the probability of making contact for medical follow-up in this sample. However, time-variant reporting of SUD treatment within the last six months did not reflect this association, and somewhat surprisingly, recent legal methadone use (i.e., OST) decreased the odds of contacting a provider. This suggests that while past treatment for SUD may boost healthcare engagement after HCV screening in this population, contemporaneous SUD treatment and OST do not seem to directly promote HCV-related healthcare under current conditions, echoing the negative association reported by Grebely et al. (2011) among Australian PWID. However, it is also possible that in this study HCV-positive participants already aware of their HCV status had been referred to medical evaluation through their OST prescriber prior to study enrollment, artificially decreasing these individuals' report of provider contact after T\&C during the study. Nonetheless, the possibility that legal methadone use did not increase the probability of seeking out HCV-related medical care among seropositive individuals is concerning given what few harm reduction services are currently available in Central Appalachia and the effectiveness of integrated services for PWID demonstrated in other settings (Grebely et al., 2007; Grebely et al., 2010; Masson et al., 2013). Finally, as suggested in previous research (McGibbon et al., 2013; McGowan et al., 2013; Morrill et al., 2005; Treloar, Newland, Rance, \& Hopwood, 2010), there may also be provider- and/or system-level biases against treating HCV among opioid-dependent individuals receiving OST, particularly PWID. In any case, this finding reinforces the notion that harm reduction, SUD treatment, and HCV-related healthcare services are not well-integrated in rural Central Appalachia.

Two characteristics promoting contact of a healthcare provider for HCV follow-up in this sample have not been reported similar prior studies. First, access to the internet nearly doubled the likelihood of healthcare contact during the subsequent study interval. This association suggests that there could be a protective benefit in online access to information regarding the health impacts and/or treatment options for HCV. In light of past research describing the potential of internet access to increase patient knowledge level, facilitate dissemination of health information, and promote "patient activism" (Magnezi et al., 2014; Pew Internet \& American Life Project, 2010; Stevenson, Kerr, Murray, \& Nazareth, 2007)— including among patients with HIV (Kalichman et al., 2002) and other chronic diseases such as cancer (Basch, Thaler, Shi, Yakren, \& Schrag, 2004)—it is possible that similar mechanisms act on HCV-seropositive individuals. Furthermore, this finding is of particular 
interest given the ongoing scarcity of internet access in the rural Central Appalachian region sampled here (Lawrence et al., 2015).

Another unexpected association promoting contact for medical follow-up was observed among recent marijuana users in this rural cohort. One study from the interferon/ribavirin era reported significant improvements in both treatment retention and efficacy among recent marijuana users (Sylvestre, 2002; Sylvestre, Clements, \& Malibu, 2006), but no other protective associations have been reported with regard to marijuana use and promotion of HCV-related care. One possible explanation is that rural PWID interested in ceasing IDU but with poor access to addiction treatment services might substitute marijuana for prescription opioids or other drugs of injection, although this hypothesis has not been systematically assessed. Further investigation of marijuana use in this population would be beneficial, particularly as daily cannabis use may accelerate progression of hepatic disease among individuals with chronic HCV (Hezode et al., 2008; Mallat, Hezode, \& Lotersztajn, 2008).

Finally, two psychiatric measures were independently associated with making contact for medical follow-up and are of particular interest given the well-established role of mental health comorbidity in determining HCV treatment eligibility (AASLD-IDSA, 2016) and frequent psychosocial impairment among individuals with chronic HCV (Fireman, Indest, Blackwell, Whitehead, \& Hauser, 2005; Modabbernia, Poustchi, \& Malekzadeh, 2013). Depressive symptomatology is a common barrier to healthcare engagement in general, including among individuals with HCV (Nguyen, Dore, Kaldor, \& Hellard, 2007; Treloar et al., 2010), so the negative association with MDD observed here is not unexpected. Moreover, depressive disorders are frequently comorbid with HCV, and depressed individuals are more likely to report symptoms, fatigue, and other impacts resulting from chronic infection (Dwight et al., 2000; Golden, O'Dwyer, \& Conroy, 2005). By contrast, participants meeting criteria for GAD displayed a strong positive association with making contact for follow-up in this sample, although few prior studies have investigated HCVrelated care in the context of anxiety disorders. No differences with regard to the adverse impacts of illness were reported among HCV-positive patients in one study (Golden et al., 2005), despite frequent associations between anxiety disorders and chronic HCV (el-Serag, Kunik, Richardson, \& Rabeneck, 2002). While no previous studies have reported an association between GAD and HCV-related healthcare engagement, it seems intuitive that individuals more likely to experience anxiety after $\mathrm{HCV}$ status disclosure and counseling are also more inclined to seek out medical care for a potentially fatal condition such as chronic HCV. Additional study could clarify the relationship between psychiatric comorbidity and healthcare-seeking behavior among people who use and inject drugs, particularly in the setting of highly prevalent non-medical prescription opioid use.

Although this study provides insight into the initial steps of HCV-related medical assessment and treatment engagement in a rarely studied population, there are limitations to consider. First, the study survey asked specifically about contacting a healthcare provider for recommended follow-up testing and evaluation, rather than receipt of such follow-up, which could explain the relatively high rate of HCV-related healthcare engagement reported by participants in this sample. However, it should be noted that given the relatively recent legalization of SEPs in Kentucky with associated disease screening programs, HCV status 
awareness and associated post-test counseling with recommendations to pursue medical follow-up are likely to rise; therefore, understanding the initial step of HCV-related healthcare engagement following T\&C is of utmost importance. Next, the proportion of participants reporting treatment-seeking and receipt may be depressed relative to present-day conditions, given that data collection occurred prior to the advent of dramatically more efficacious, better tolerated, and attenuated direct-acting antiviral regimens ( $\mathrm{Li} \&$ De Clercq, 2017), as outlined previously. Finally, as with most research on substance-using populations, the analyses presented here relied on self-reported data, which can be subject to underreporting or over-reporting due to social desirability and recall biases, including the primary outcome variable. However, recall bias is expected to be minimized by the use of timevarying measures pertaining to the prior six months or less, and previous studies have found self-reported behavior from people who use and inject drugs to be a reliable source of data (Darke, 1998; Kokkevi, Richardson, Palermou, \& Leventakou, 1997).

In summary, additional intervention and research in rural populations characterized by high $\mathrm{HCV}$ transmission risk and complex barriers to initiation and engagement in HCV-related care are warranted. For example, intervening at the time of $\mathrm{T} \& \mathrm{C}$ with active referrals to HCV-related follow-up care at the time of screening might present a promising and effective means of increasing the proportion of treatment-eligible rural patients reaching points further downstream in the cascade of HCV-related medical care. Such interventional study might present particular benefit to individuals receiving disease screening and/or harm reduction services such as OST and SEPs, which present fleeting opportunities for rural PWID to be linked to HCV-related care in resource-poor regions with relatively scarce medical and social support resources. However, the lack of HCV treatment providers in many rural areas, and Appalachian Kentucky in particular, is a major barrier. Based on research in urban settings, integrated programs offering psychiatric, SUD, harm reduction, and medical care targeted to underserved populations characterized by poor access to preventive resources would seem to promise highest likelihood of benefit. In addition, it would be interesting to evaluate HCV-related healthcare contact, treatment-seeking, and treatment receipt in the era of newer, highly efficacious, and substantially more tolerable direct-acting antiviral agents, as well as increased health insurance coverage and more widely available harm reduction services in this long-underserved population.

\section{Acknowledgments}

This research was supported by the National Institutes of Health, National Institutes on Drug Abuse (grant numbers R01DA024598 and R01DA033862 awarded to J.R. Havens). D.B. Stephens was supported by NIH T32 training grant TL1RR033172.

\section{References}

AASLD-IDSA. Recommendations for Testing, Managing, and Treating Hepatitis C. 2016. Retrieved from http://www.hcvguidelines.org

Allison PD. Discrete-time methods for the analysis of event histories. Sociological Methodology. 1982; 13(1):61-98.

Appalachian Regional Commission. An analysis of mental health and substance abuse disparities \& access to treatment services in the Appalachian region. Appalachian Regional Commission. 2008. Retrieved from http://www.arc.gov/research/researchreportdetails.asp?REPORT_ID=71 
Astell-Burt T, Flowerdew R, Boyle PJ, Dillon JF. Does geographic access to primary healthcare influence the detection of hepatitis C? Soc Sci Med. 2011; 72(9):1472-1481. [PubMed: 21481509]

Basch EM, Thaler HT, Shi W, Yakren S, Schrag D. Use of information resources by patients with cancer and their companions. Cancer. 2004; 100(11):2476-2483. [PubMed: 15160355]

Birkhead GS, Klein SJ, Candelas AR, O’Connell DA, Rothman JR, Feldman IS, Tsui DS, Cotroneo RA, Flanigan CA. Integrating multiple programme and policy approaches to hepatitis $\mathrm{C}$ prevention and care for injection drug users: a comprehensive approach. Int J Drug Policy. 2007; 18(5):417425. [PubMed: 17854731]

Brammer, J. [April 22, 2014] Beshear says more than 413,000 Kentuckians signed up for health care in state exchange. Lexington Herald-Leader. 2014. Retrieved from http://www.kentucky.com/ 2014/04/22/3207241/beshear-says-more-than-413000.html

Centers for Disease Control and Prevention. Recommendations for prevention and control of hepatitis $\mathrm{C}$ virus (HCV) infection and HCV-related chronic disease. Centers for Disease Control and Prevention. MMWR Recomm Rep. 1998; 47(RR-19):1-39.

Centers for Disease Control and Prevention. Viral Hepatitis Surveillance - United States, 2014. 2016. Retrieved from https://www.cdc.gov/hepatitis/statistics/2014surveillance/index.htm

Cullen W, Stanley J, Langton D, Kelly Y, Bury G. Management of hepatitis C among drug users attending general practice in Ireland: baseline data from the Dublin area hepatitis $\mathrm{C}$ in general practice initiative. Eur J Gen Pract. 2007; 13(1):5-12. [PubMed: 17366287]

Darke S. Self-report among injecting drug users: a review. Drug Alcohol Depend. 1998; 51(3):253263. discussion 267-258. [PubMed: 9787998]

Denniston MM, Klevens RM, McQuillan GM, Jiles RB. Awareness of infection, knowledge of hepatitis $\mathrm{C}$, and medical follow-up among individuals testing positive for hepatitis C: National Health and Nutrition Examination Survey 2001-2008. Hepatology. 2012; 55(6):1652-1661. [PubMed: 22213025]

Department for Public Health. HIV Prevention Program. 2015. Retrieved from http:// chfs.ky.gov/dph/epi/HIVAIDS/prevention.htm

Des Jarlais DC, Nugent A, Solberg A, Feelemyer J, Mermin J, Holtzman D. Syringe Service Programs for Persons Who Inject Drugs in Urban, Suburban, and Rural Areas - United States, 2013. MMWR Morb Mortal Wkly Rep. 2015; 64(48):1337-1341. [PubMed: 26655918]

Dwight MM, Kowdley KV, Russo JE, Ciechanowski PS, Larson AM, Katon WJ. Depression, fatigue, and functional disability in patients with chronic hepatitis C. J Psychosom Res. 2000; 49(5):311317. [PubMed: 11164055]

el-Serag HB, Kunik M, Richardson P, Rabeneck L. Psychiatric disorders among veterans with hepatitis C infection. Gastroenterology. 2002; 123(2):476-482. [PubMed: 12145801]

Environmental Systems Research Institute. ESRI Data and Maps 10 (StreetMap North America). Redlands, CA: 2010.

Fireman M, Indest DW, Blackwell A, Whitehead AJ, Hauser P. Addressing tri-morbidity (hepatitis C, psychiatric disorders, and substance use): the importance of routine mental health screening as a component of a comanagement model of care. Clin Infect Dis. 2005; (40 Suppl 5):S286-291. [PubMed: 15768336]

Gallup Well-Being. In U.S., Uninsured Rate Sinks to 13.4\% in Second Quarter. 2014. Retrieved from http://www.gallup.com/poll/172403/uninsured-rate-sinks-second-quarter.aspx

Golden J, O'Dwyer AM, Conroy RM. Depression and anxiety in patients with hepatitis C: prevalence, detection rates and risk factors. Gen Hosp Psychiatry. 2005; 27(6):431-438. [PubMed: 16271658]

Grebely J, Alavi M, Micallef M, Dunlop AJ, Balcomb AC, Phung N, Weltman MD, Day CA, Treloar C, Bath N, Haber PS, Dore GJ. Treatment for hepatitis C virus infection among people who inject drugs attending opioid substitution treatment and community health clinics: the ETHOS Study. Addiction. 2016; 111(2):311-319. [PubMed: 26451534]

Grebely J, Dore GJ. Can hepatitis C virus infection be eradicated in people who inject drugs? Antiviral Res. 2014; 104:62-72. [PubMed: 24468275]

Grebely J, Genoway K, Khara M, Duncan F, Viljoen M, Elliott D, Raffa JD, DeVlaming S, Conway B. Treatment uptake and outcomes among current and former injection drug users receiving directly 
observed therapy within a multidisciplinary group model for the treatment of hepatitis $\mathrm{C}$ virus infection. Int J Drug Policy. 2007; 18(5):437-443. [PubMed: 17854734]

Grebely J, Genoway KA, Raffa JD, Dhadwal G, Rajan T, Showler G, Kalousek K, Duncan F, Tyndall MW, Fraser C, Conway B, Fischer B. Barriers associated with the treatment of hepatitis C virus infection among illicit drug users. Drug Alcohol Depend. 2008; 93(1-2):141-147. [PubMed: 17997050]

Grebely J, Knight E, Genoway KA, Viljoen M, Khara M, Elliott D, Gallagher L, Storms M, Raffa JD, DeVlaming S, Duncan F, Conway B. Optimizing assessment and treatment for hepatitis $\mathrm{C}$ virus infection in illicit drug users: a novel model incorporating multidisciplinary care and peer support. Eur J Gastroenterol Hepatol. 2010; 22(3):270-277. [PubMed: 20425880]

Grebely J, Raffa JD, Lai C, Krajden M, Kerr T, Fischer B, Tyndall MW. Low uptake of treatment for hepatitis $\mathrm{C}$ virus infection in a large community-based study of inner city residents. J Viral Hepat. 2009; 16(5):352-358. [PubMed: 19226330]

Grebely J, Robaeys G, Bruggmann P, Aghemo A, Backmund M, Bruneau J, Byrne J, Dalgard O, Feld JJ, Hellard M, Hickman M, Kautz A, Litwin A, Lloyd AR, Mauss S, Prins M, Swan T, Schaefer M, Taylor LE, Dore GJ. Recommendations for the management of hepatitis C virus infection among people who inject drugs. Int J Drug Policy. 2015; 26(10):1028-1038. [PubMed: 26282715]

Havens JR, Lofwall MR, Frost SD, Oser CB, Leukefeld CG, Crosby RA. Individual and network factors associated with prevalent hepatitis $\mathrm{C}$ infection among rural Appalachian injection drug users. Am J Public Health. 2013; 103(1):e44-52. DOI: 10.2105/AJPH.2012.300874

Heckathorn D. Respondent-driven sampling: A new approach to the study of hidden populations. Social Problems. 1997; 44(2):174-199.

Hezode C, Zafrani ES, Roudot-Thoraval F, Costentin C, Hessami A, Bouvier-Alias M, Medkour F, Pawlostky JM, Lotersztajn S, Mallat A. Daily cannabis use: a novel risk factor of steatosis severity in patients with chronic hepatitis C. Gastroenterology. 2008; 134(2):432-439. [PubMed: 18242211]

Hosmer, D., Lemeshow, S. Applied Logistic Regression. New York: Wiley; 1989.

Kalichman SC, Weinhardt L, Benotsch E, DiFonzo K, Luke W, Austin J. Internet access and Internet use for health information among people living with HIV-AIDS. Patient Educ Couns. 2002; 46(2): 109-116. [PubMed: 11867240]

Kentucky Legislative Research Commission. [June 20, 2005] Sale and disposal of hypodermic syringes or needles, KRS 217.177. 2005. Retrieved from http://www.lrc.ky.gov/krs/217-00/177.pdf

Kokkevi A, Richardson C, Palermou B, Leventakou V. Reliability of drug dependents' self-reports. Drug Alcohol Depend. 1997; 45(1-2):55-61. [PubMed: 9179507]

Lawrence, S., Oliver, L., Hogan, M., VanLear, S., Baller, J., Horrigan, J., Johnson, M., Patterson, JS., Stelfox, A., Watts, D. Program Evaluation of the Appalachian Regional Commission's Telecommunications and Technology Projects: FY 2004-FY 2010. 2015. Retrieved from https:// www.arc.gov/research/researchreportdetails.asp?REPORT_ID $=120$

Li G, De Clercq E. Current therapy for chronic hepatitis C: The role of direct-acting antivirals. Antiviral Res. 2017

Lim SS, Vos T, Flaxman AD, Danaei G, Shibuya K, Adair-Rohani H, Memish ZA. A comparative risk assessment of burden of disease and injury attributable to 67 risk factors and risk factor clusters in 21 regions, 1990-2010: a systematic analysis for the Global Burden of Disease Study 2010. Lancet. 2012; 380(9859):2224-2260. [PubMed: 23245609]

Ly KN, Xing J, Klevens RM, Jiles RB, Ward JW, Holmberg SD. The increasing burden of mortality from viral hepatitis in the United States between 1999 and 2007. Ann Intern Med. 2012; 156(4): 271-278. [PubMed: 22351712]

Magnezi R, Grosberg D, Novikov I, Ziv A, Shani M, Freedman LS. Characteristics of patients seeking health information online via social health networks versus general Internet sites: a comparative study. Inform Health Soc Care. 2014

Mallat A, Hezode C, Lotersztajn S. Environmental factors as disease accelerators during chronic hepatitis C. J Hepatol. 2008; 48(4):657-665. [PubMed: 18279998]

Martin NK, Vickerman P, Grebely J, Hellard M, Hutchinson SJ, Lima VD, Foster GR, Dillon JF, Goldberg DJ, Dore GJ, Hickman M. Hepatitis C virus treatment for prevention among people who 
inject drugs: Modeling treatment scale-up in the age of direct-acting antivirals. Hepatology. 2013; 58(5):1598-1609. [PubMed: 23553643]

Masson CL, Delucchi KL, McKnight C, Hettema J, Khalili M, Min A, Jordan AE, Pepper N, Hall J, Hengl NS, Young C, Shopshire MS, Manuel JK, Coffin L, Hammer H, Shapiro B, Seewald RM, Bodenheimer HC Jr, Sorensen JL, Des Jarlais DC, Perlman DC. A randomized trial of a hepatitis care coordination model in methadone maintenance treatment. Am J Public Health. 2013; 103(10):e81-88.

McGibbon E, Bornschlegel K, Balter S. Half a diagnosis: gap in confirming infection among hepatitis C antibody-positive patients. Am J Med. 2013; 126(8):718-722. [PubMed: 23786667]

McGowan CE, Monis A, Bacon BR, Mallolas J, Goncales FL, Goulis I, Poordad F, Afdhal N, Zeuzem S, Piratvisuth T, Marcellin P, Fried MW. A global view of hepatitis C: physician knowledge, opinions, and perceived barriers to care. Hepatology. 2013; 57(4):1325-1332. [PubMed: 23315914]

Mehta SH, Genberg BL, Astemborski J, Kavasery R, Kirk GD, Vlahov D, Strathdee SA, Thomas DL. Limited uptake of hepatitis C treatment among injection drug users. J Community Health. 2008; 33(3):126-133. [PubMed: 18165889]

Modabbernia A, Poustchi H, Malekzadeh R. Neuropsychiatric and psychosocial issues of patients with hepatitis C infection: a selective literature review. Hepat Mon. 2013; 13(1):e8340. [PubMed: 23550100]

Monnet E, Ramee C, Minello A, Jooste V, Carel D, Di Martino V. Socioeconomic context, distance to primary care and detection of hepatitis C: a French population-based study. Soc Sci Med. 2008; 66(5):1046-1056. [PubMed: 18164525]

Morrill JA, Shrestha M, Grant RW. Barriers to the treatment of hepatitis C. Patient, provider, and system factors. J Gen Intern Med. 2005; 20(8):754-758. [PubMed: 16050887]

Mravcik V, Strada L, Stolfa J, Bencko V, Groshkova T, Reimer J, Schulte B. Factors associated with uptake, adherence, and efficacy of hepatitis $\mathrm{C}$ treatment in people who inject drugs: a literature review. Patient Prefer Adherence. 2013; 7:1067-1075. [PubMed: 24204126]

Nelson PK, Mathers BM, Cowie B, Hagan H, Des Jarlais D, Horyniak D, Degenhardt L. Global epidemiology of hepatitis B and hepatitis $\mathrm{C}$ in people who inject drugs: results of systematic reviews. Lancet. 2011; 378(9791):571-583. [PubMed: 21802134]

Nguyen OK, Dore GJ, Kaldor JM, Hellard ME. Recruitment and follow-up of injecting drug users in the setting of early hepatitis C treatment: insights from the ATAHC study. Int J Drug Policy. 2007; 18(5):447-451. [PubMed: 17854736]

Pew Internet \& American Life Project. Chronic Disease and the Internet. 2010. Retrieved from http:// www.pewinternet.org/files/old-media/Files/Reports/2010/PIP_Chronic_Disease_with_topline.pdf

Rehermann B. HCV in 2015: Advances in hepatitis C research and treatment. Nat Rev Gastroenterol Hepatol. 2016; 13(2):70-72. [PubMed: 26790365]

Sheehan DV, Lecrubier Y, Sheehan KH, Amorim P, Janavs J, Weiller E, Hergueta T, Baker R, Dunbar GC. The Mini-International Neuropsychiatric Interview (M.I.N.I.): the development and validation of a structured diagnostic psychiatric interview for DSM-IV and ICD-10. J Clin Psychiatry. 1998; (59 Suppl 20):22-33. quiz 34-57.

Singer JD, Willett JB. It's about time: Using discrete-time survival analysis to study duration and the timing of events. Journal of Educational and Behavioral Statistics. 1993; 18(2):155-195.

Singer, JD., Willett, JB. Applied Longitudinal Data Analysis: Modeling Change and Event Occurrence. New York: Oxford University Press; 2003.

Smith BD, Morgan RL, Beckett GA, Falck-Ytter Y, Holtzman D, Teo CG, Jewett A, Baack B, Rein DB, Patel N, Alter M, Yartel A, Ward JW. Recommendations for the identification of chronic hepatitis C virus infection among persons born during 1945-1965. MMWR Recomm Rep. 2012; 61(RR-4):1-32.

Spradling PR, Tong X, Rupp L, Moorman AC, Lu M, Teshale EH, Gordon SC, Vijayadeva V, Boscarino JA, Schmidt MA, Holmberg SD. Trends in HCV RNA testing among HCV antibody positive persons in care, 2003-2010. Clin Infect Dis. 2014; 59(7):976-81. [PubMed: 24991025]

Stensland, JMC., Sutton, J. An Analysis of the Financial Conditions of Health Care Institutions in the Appalachian Region and their Economic Impacts. Washington DC: 2002. 
Stepanova M, Kanwal F, El-Serag HB, Younossi ZM. Insurance status and treatment candidacy of hepatitis C patients: analysis of population-based data from the United States. Hepatology. 2011; 53(3):737-745. [PubMed: 21319199]

Stevenson FA, Kerr C, Murray E, Nazareth I. Information from the Internet and the doctor-patient relationship: the patient perspective--a qualitative study. BMC Fam Pract. 2007; 8:47. [PubMed: 17705836]

Stoove MA, Gifford SM, Dore GJ. The impact of injecting drug use status on hepatitis C-related referral and treatment. Drug Alcohol Depend. 2005; 77(1):81-86. [PubMed: 15607844]

Strathdee SA, Latka M, Campbell J, O’Driscoll PT, Golub ET, Kapadia F, Pollini RA, Garfein RS, Thomas DL, Hagan H. Factors associated with interest in initiating treatment for hepatitis C Virus (HCV) infection among young HCV-infected injection drug users. Clin Infect Dis. 2005; (40 Suppl 5):S304-312. [PubMed: 15768339]

Sylvestre DL. Treating hepatitis $\mathrm{C}$ in methadone maintenance patients: an interim analysis. Drug Alcohol Depend. 2002; 67(2):117-123. [PubMed: 12095661]

Sylvestre DL, Clements BJ, Malibu Y. Cannabis use improves retention and virological outcomes in patients treated for hepatitis C. Eur J Gastroenterol Hepatol. 2006; 18(10):1057-1063. [PubMed: 16957511]

Treloar C, Hull P, Dore GJ, Grebely J. Knowledge and barriers associated with assessment and treatment for hepatitis C virus infection among people who inject drugs. Drug Alcohol Rev. 2012; 31(7):918-924. [PubMed: 22612899]

Treloar C, Newland J, Rance J, Hopwood M. Uptake and delivery of hepatitis C treatment in opiate substitution treatment: perceptions of clients and health professionals. J Viral Hepat. 2010; 17(12): 839-844. [PubMed: 20070504]

Trepka MJ, Zhang G, Leguen F, Obiaja K, Malow RM, De La Rosa M. Benefits and adverse effects of hepatitis C screening: early results of a screening program. J Public Health Manag Pract. 2007; 13(3):263-269. [PubMed: 17435493]

U.S. Department of Health and Human Services. Profiles of Affordable Care Act Coverage Expansion Enrollment for Medicaid/CHIP and the Health Insurance Marketplace, 10-1-2013 to 3-31-2014. 2014. Retrieved from http://aspe.hhs.gov/health/reports/2014/MarketPlaceEnrollment/Apr2014/ Marketplace_StateSum.cfm

US Food and Drug Administration. Home Access ${ }^{\circledR}$ Hepatitis C Check and Hepatitis C Check Express Summary of Safety and Effectivess. 1999. Retrieved from http://www.accessdata.fda.gov/ cdrh_docs/pdf/P980046b.pdf

Volz, E., Wejnert, C., Cameron, C., Spiller, M., Barash, V., Degani, I., Heckathorn, D. Respondentdriven Sampling Analysis Tool (RDSAT) Version 7.1. Ithaca, NY: Cornell University; 2012.

Wiessing L, Ferri M, Grady B, Kantzanou M, Sperle I, Cullen KJ, EMCDDA DRID Group. Hatzakis A, Prins M, Vickerman P, Lazarus JV, Hope VD, Mathei C. Hepatitis C virus infection epidemiology among people who inject drugs in Europe: a systematic review of data for scaling up treatment and prevention. PLoS One. 2014; 9(7):e103345. [PubMed: 25068274]

Young AM, Jonas AB, Havens JR. Social networks and HCV viraemia in anti-HCV-positive rural drug users. Epidemiol Infect. 2013; 141(2):402-411. [PubMed: 22717190]

Zibbell JE, Iqbal K, Patel RC, Suryaprasad A, Sanders KJ, Moore-Moravian L, Serrecchia J, Blankenship S, Ward JW, Holtzman D. Increases in hepatitis C virus infection related to injection drug use among persons aged $</=30$ years - Kentucky, Tennessee, Virginia, and West Virginia, 2006-2012. MMWR Morb Mortal Wkly Rep. 2015; 64(17):453-458. [PubMed: 25950251] 


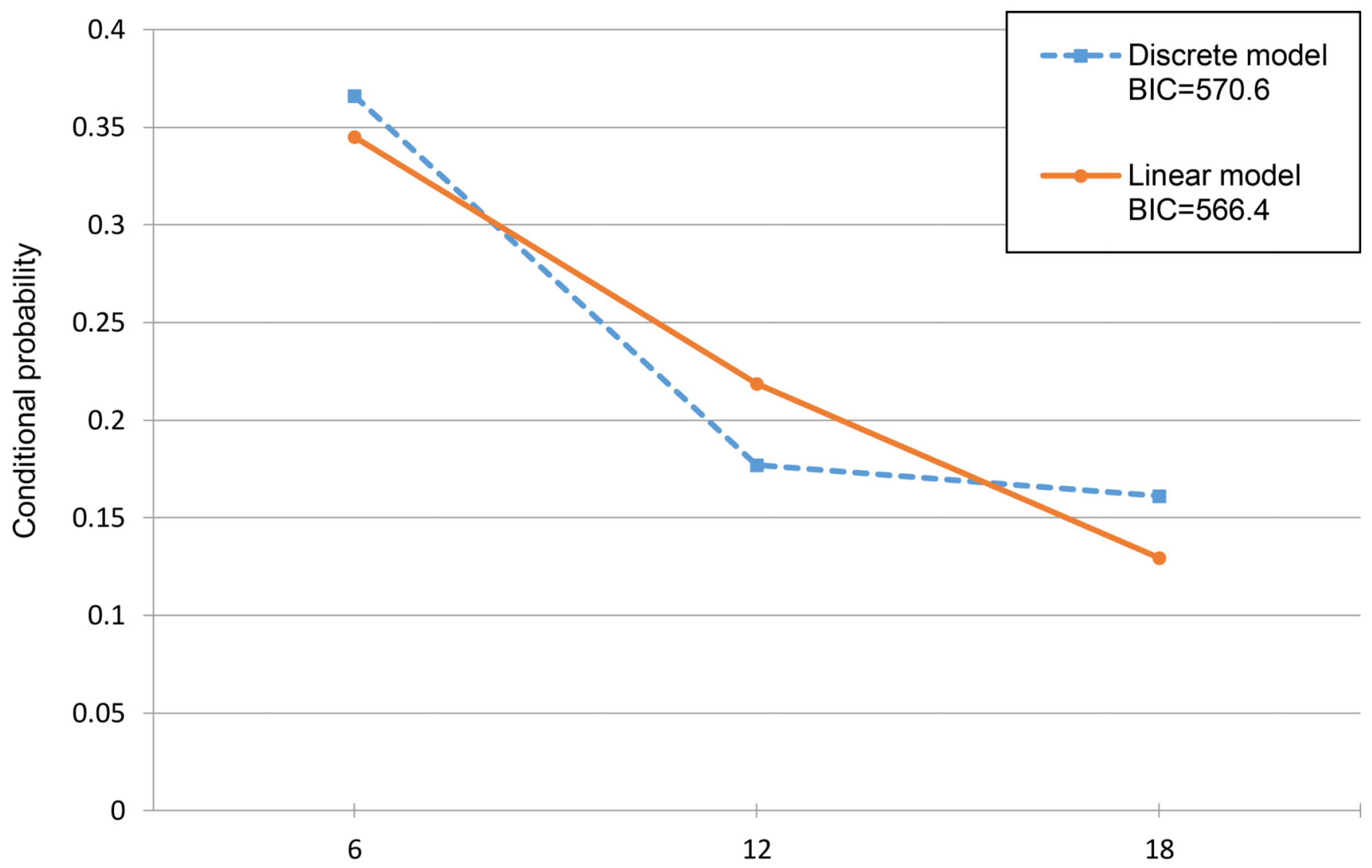

Months since $\mathrm{HCV}+\mathrm{T} \& \mathrm{C}$

Figure 1.

RDS-adjusted hazard functions depicting conditional probability of contacting a healthcare provider for medical follow-up after HCV-positive serotesting and post-test counseling. No difference was detected between the fully discrete and linear models for the main effect of time $(\mathrm{p}=0.68)$. $\mathrm{BIC}=$ Bayesian information criterion. 


\section{Table 1}

Description of HCV medical care-related behaviors and treatment uptake after positive serotest and counseling $(\mathrm{N}=254)$

\begin{tabular}{|l|c|c|}
\hline Aspect of HCV care & $\begin{array}{c}\text { Sample total } \\
\boldsymbol{n}(\boldsymbol{\%})\end{array}$ & $\begin{array}{c}\text { Population estimate } \\
\mathbf{\%}(\mathbf{9 5 \%} \mathbf{C I})\end{array}$ \\
\hline Contacted provider for follow-up evaluation & $150(59.1)$ & $51.8(44.5-58.9)$ \\
\hline Endorsed seeking treatment for HCV & $35(13.8)$ & $12.4(8.4-8.1)$ \\
\hline Received treatment for HCV & $21(8.3)$ & $7.8(4.5-13.1)$ \\
\hline
\end{tabular}


Table 2

Description of sample and bivariate associations with contacting a healthcare provider for follow-up after HCV-positive serotest and counseling $(\mathrm{N}=254)^{1}$

\begin{tabular}{|c|c|c|c|c|}
\hline Characteristic & $\begin{array}{l}\text { Sample total } \\
n(\%)\end{array}$ & $\begin{array}{l}\text { Odds } \\
\text { Ratio }\end{array}$ & $95 \% \mathrm{CI}$ & $\begin{array}{c}p- \\
\text { value }\end{array}$ \\
\hline \multicolumn{5}{|l|}{ Time-invariant } \\
\hline Male & $152(59.8)$ & 0.73 & $0.44-1.20$ & 0.209 \\
\hline White & $241(94.9)$ & 0.92 & $0.32-2.66$ & 0.874 \\
\hline Age (years) - mean (SD) & $33.1(8.0)$ & 0.99 & $0.96-1.02$ & 0.213 \\
\hline Heterosexual & $23(9.1)$ & 0.58 & $0.32-2.66$ & 0.198 \\
\hline Married & $60(23.6)$ & 0.73 & $0.42-1.27$ & 0.270 \\
\hline Number of dependents - mean (SD) & $0.9(1.4)$ & 1.03 & $0.86-1.25$ & 0.716 \\
\hline Education (months) - mean (SD) & $137.3(29.3)$ & 1.00 & $0.99-1.01$ & 0.454 \\
\hline Monthly income (US \$) - mean (SD) & $1283.6(1949.6)$ & 1.01 & $0.99-1.01$ & 0.284 \\
\hline$\%$ of income legal - mean (SD) & $93.8(19.8)$ & 0.98 & $0.97-1.00$ & 0.036 \\
\hline Most often unemployed (last 3 years) & $78(30.7)$ & 0.95 & $0.56-1.59$ & 0.832 \\
\hline Driver's license and access to vehicle & $92(36.2)$ & 0.98 & $0.58-1.64$ & 0.930 \\
\hline Major depressive disorder & $68(26.8)$ & 0.95 & $0.55-1.62$ & 0.839 \\
\hline Generalized anxiety disorder & $73(28.7)$ & 1.78 & $1.04-3.05$ & 0.036 \\
\hline Antisocial personality disorder & $76(29.9)$ & 0.86 & $0.51-1.47$ & 0.589 \\
\hline Post-traumatic stress disorder & $35(13.8)$ & 0.89 & $0.44-1.83$ & 0.754 \\
\hline Incident $\mathrm{HCV}$ during SNAP & $30(11.8)$ & 0.88 & $0.37-2.08$ & 0.770 \\
\hline Aware of $\mathrm{HCV}+$ status prior to study & $68(26.8)$ & 1.45 & $0.84-2.50$ & 0.185 \\
\hline 25 of 6 general HCV questions correct & $234(92.1)$ & 1.56 & $0.62-3.94$ & 0.343 \\
\hline Aware of HCV treatment & $218(85.8)$ & 1.22 & $0.63-2.36$ & 0.558 \\
\hline \multicolumn{5}{|l|}{ Time-varying } \\
\hline Health insurance coverage ${ }^{2}$ & $80(31.5)$ & 1.97 & $1.19-3.27$ & 0.008 \\
\hline "Good" or "excellent" health status & $164(64.6)$ & 0.90 & $0.56-1.56$ & 0.679 \\
\hline Chronic medical condition & $106(41.7)$ & 1.11 & $0.67-1.83$ & 0.691 \\
\hline Taking legally prescribed medication & $86(33.9)$ & 1.44 & $0.81-2.56$ & 0.216 \\
\hline Receiving government benefits for disability & $36(14.2)$ & 1.97 & $0.99-3.92$ & 0.055 \\
\hline Access to internet & $151(59.5)$ & 1.88 & $1.19-2.97$ & 0.007 \\
\hline Incarceration (last 30 days) & $68(26.8)$ & 1.18 & $0.66-2.11$ & 0.574 \\
\hline Distance to hospital $(\mathrm{km})$ - mean $(\mathrm{SD})^{3}$ & $11.3(10.2)$ & 0.99 & $0.96-1.01$ & 0.246 \\
\hline Social support out-degree - mean (SD) & $2.0(1.2)$ & 1.12 & $0.93-1.34$ & 0.222 \\
\hline \multicolumn{5}{|l|}{ Lifetime behavior (reported at time of HCV+ test) } \\
\hline Received substance abuse treatment & $152(59.8)$ & 1.96 & $1.20-3.20$ & 0.008 \\
\hline Incarceration & $222(87.4)$ & 1.35 & $0.62-2.94$ & 0.450 \\
\hline Drug overdose & $72(28.4)$ & 1.55 & $0.89-2.67$ & 0.119 \\
\hline Injection drug use & $240(94.5)$ & 1.88 & $0.60-6.11$ & 0.293 \\
\hline
\end{tabular}




\begin{tabular}{|c|c|c|c|c|}
\hline Characteristic & $\begin{array}{l}\text { Sample total } \\
n(\%)\end{array}$ & $\begin{array}{l}\text { Odds } \\
\text { Ratio }\end{array}$ & $95 \% \mathrm{CI}$ & $\begin{array}{c}p- \\
\text { value }\end{array}$ \\
\hline Heroin use & $107(42.1)$ & 1.13 & $0.70-1.83$ & 0.621 \\
\hline Illicit methadone use & $240(94.5)$ & 0.32 & $0.13-0.76$ & 0.010 \\
\hline Legal methadone use & $63(24.8)$ & 0.91 & $0.53-1.56$ & 0.733 \\
\hline Illicit buprenophine use & $183(72.1)$ & 1.05 & $0.62-1.76$ & 0.868 \\
\hline Legal buprenorphine use & $30(11.8)$ & 1.53 & $0.69-3.41$ & 0.295 \\
\hline Illicit OxyContin ${ }^{\circledR}$ use $^{4}$ & $249(98.0)$ & 2.44 & $0.34-17.42$ & 0.374 \\
\hline Other prescription opioid use & $245(96.5)$ & 0.31 & $0.06-1.67$ & 0.172 \\
\hline Sedative, hypnotic, or tranquilizer use & $238(93.7)$ & 0.58 & $0.26-1.33$ & 0.199 \\
\hline Barbiturate use & $43(16.9)$ & 0.83 & $0.45-1.51$ & 0.537 \\
\hline Crack use & 197 (77.6) & 0.92 & $0.47-1.82$ & 0.819 \\
\hline Cocaine use & $240(94.5)$ & 0.64 & $0.23-1.82$ & 0.405 \\
\hline Methamphetamine use & $113(44.5)$ & 0.87 & $0.54-1.44$ & 0.630 \\
\hline Oral amphetamine use & $86(33.9)$ & 0.83 & $0.49-1.40$ & 0.480 \\
\hline Marijuana use & $247(97.2)$ & 0.34 & $0.08-1.39$ & 0.133 \\
\hline Hallucinogen use & $139(54.7)$ & 1.01 & $0.62-1.65$ & 0.954 \\
\hline Polysubstance use & $246(96.9)$ & 0.84 & $0.14-4.92$ & 0.845 \\
\hline \multicolumn{5}{|l|}{ Recent behavior (last six months) } \\
\hline Substance abuse treatment & $42(16.5)$ & 1.01 & $0.59-1.74$ & 0.973 \\
\hline Drug overdose & $10(3.9)$ & 1.63 & $0.46-5.74$ & 0.446 \\
\hline Alcohol use to intoxication & $128(50.4)$ & 1.02 & $0.63-1.64$ & 0.946 \\
\hline Injection drug use & $170(66.9)$ & 0.95 & $0.59-1.52$ & 0.818 \\
\hline Sharing of any IDU equipment & $72(28.4)$ & 1.08 & $0.59-1.98$ & 0.803 \\
\hline Heroin use & $12(4.7)$ & 2.19 & $0.65-7.43$ & 0.208 \\
\hline Illicit methadone use & $144(56.7)$ & 1.48 & $0.93-2.35$ & 0.100 \\
\hline Legal methadone use & $9(3.5)$ & 0.44 & $0.10-1.95$ & 0.277 \\
\hline Illicit buprenorphine use & $130(51.2)$ & 1.55 & $0.97-2.50$ & 0.068 \\
\hline Legal buprenorphine use & $23(9.1)$ & 1.69 & $0.66-4.34$ & 0.275 \\
\hline OxyContin ${ }^{\circledR}$ use $^{3}$ & $194(76.4)$ & 1.35 & $0.80-2.28$ & 0.258 \\
\hline Other prescription opioid use & $201(79.1)$ & 1.22 & $0.75-1.98$ & 0.431 \\
\hline Sedative, hypnotic or tranquilizer use & $195(76.8)$ & 1.43 & $0.86-2.39$ & 0.166 \\
\hline Barbiturate use & $8(3.2)$ & 2.89 & $0.93-8.99$ & 0.066 \\
\hline Crack use & $40(15.8)$ & 1.67 & $0.85-3.26$ & 0.134 \\
\hline Cocaine use & $80(31.5)$ & 1.05 & $0.61-1.82$ & 0.849 \\
\hline Methamphetamine use & $20(7.9)$ & 1.60 & $0.62-4.15$ & 0.329 \\
\hline Oral amphetamine use & $38(15.0)$ & 1.51 & $0.74-3.05$ & 0.257 \\
\hline Marijuana use & $170(66.9)$ & 1.72 & $1.07-2.78$ & 0.026 \\
\hline Hallucinogen use & $5(2.0)$ & 1.38 & $0.18-10.70$ & 0.756 \\
\hline Polysubstance use & $225(88.6)$ & 1.35 & $0.76-2.40$ & 0.310 \\
\hline
\end{tabular}


${ }^{1}$ Adjusted for respondent-driven sampling

2 Private insurance, Medicaid, or Medicare

${ }_{n=244}$, excluding 10 participants who moved from study area

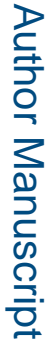

${ }^{4}$ Includes original and abuse-deterrent formulations of OxyContin ${ }^{\circledR}$ 


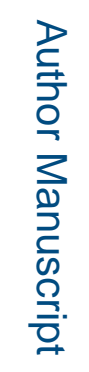

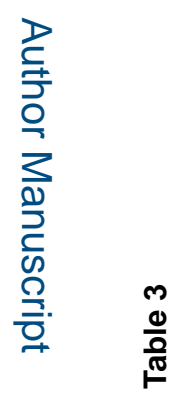

를
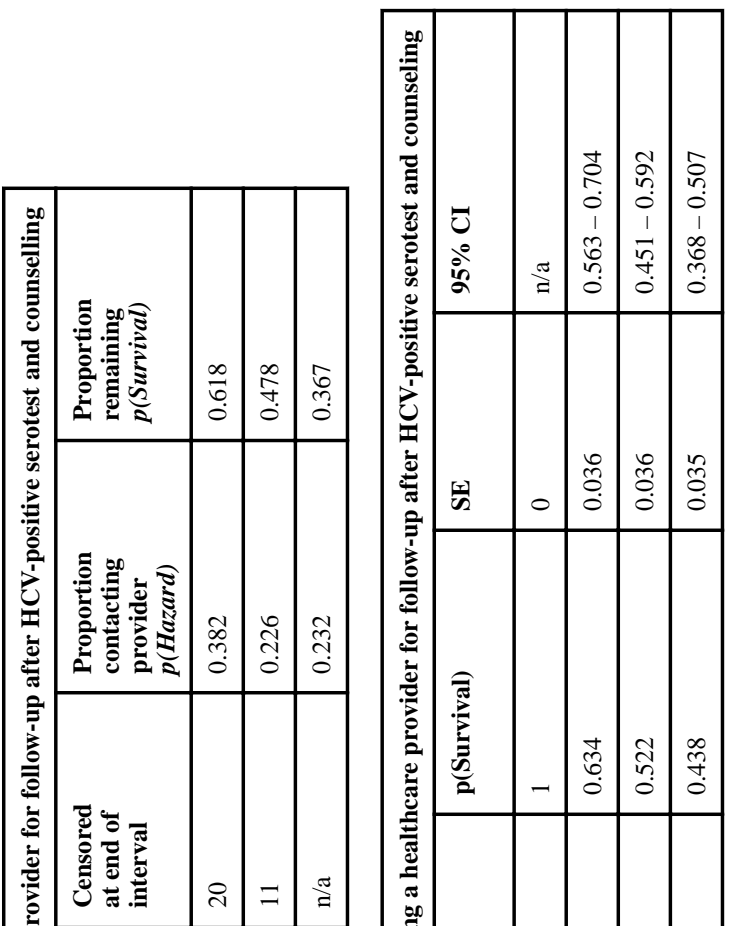

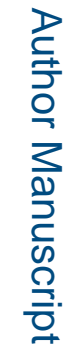
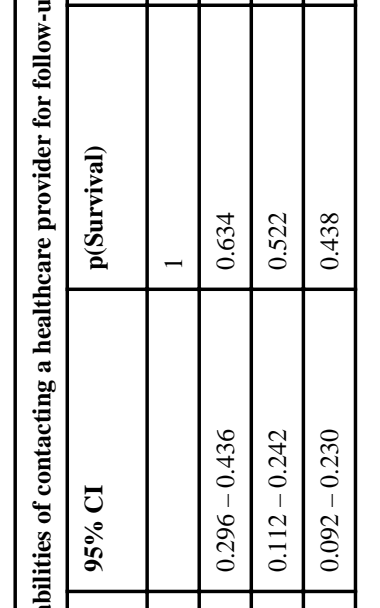

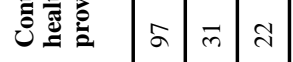
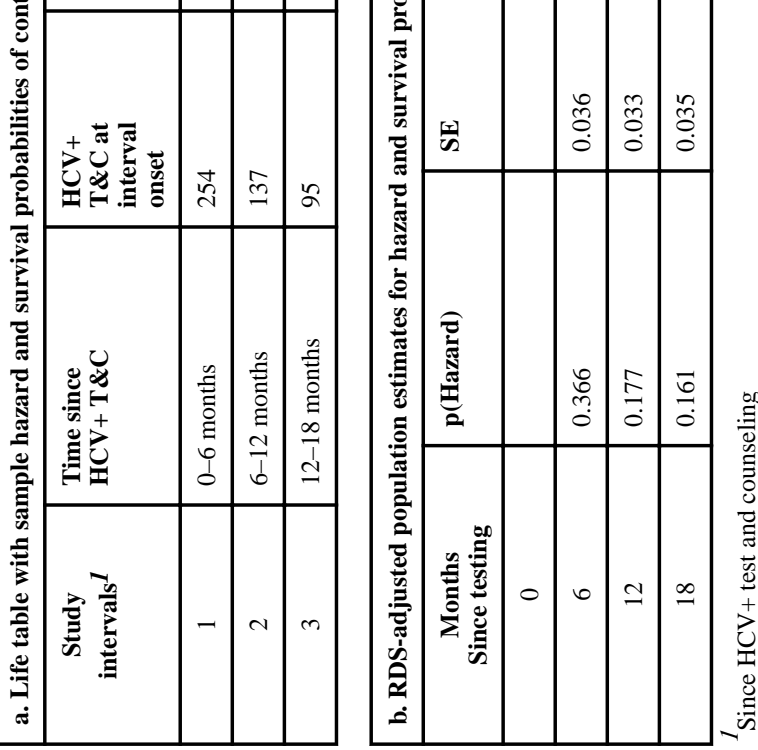

Int J Drug Policy. Author manuscript; available in PMC 2018 September 01. 
Table 4

Predictors of contacting a healthcare provider for follow-up after HCV-positive serotest and counseling: linear time model $(\mathrm{N}=254)^{l}$

\begin{tabular}{|l|c|c|c|}
\hline Variable & $\begin{array}{c}\text { Adjusted } \\
\text { Odds Ratio }\end{array}$ & $\begin{array}{c}\text { 95\% Confidence } \\
\text { Interval }\end{array}$ & p-value \\
\hline Time (per study interval) & 0.59 & $0.43-0.80$ & 0.001 \\
\hline Previous HCV+ status awareness & 1.70 & $0.93-3.08$ & 0.083 \\
\hline Health insurance $^{2}$ & 2.06 & $1.20-3.53$ & 0.009 \\
\hline Access to internet & 1.83 & $1.15-2.92$ & 0.011 \\
\hline Major depressive disorder & 0.47 & $0.23-0.96$ & 0.039 \\
\hline Generalized anxiety disorder & 2.63 & $1.33-5.18$ & 0.005 \\
\hline Ever received substance abuse treatment & 1.67 & $1.01-2.75$ & 0.045 \\
\hline Ever used illicit methadone & 0.33 & $0.14-0.82$ & 0.016 \\
\hline Legal methadone use (last 6 months) & 0.21 & $0.05-0.90$ & 0.035 \\
\hline Marijuana use (last 6 months) & 1.76 & $1.09-2.84$ & 0.021 \\
\hline
\end{tabular}

${ }^{1}$ Discrete-time survival analysis adjusted for RDS

2

2 Includes private insurance, Medicaid, or Medicare reported at onset of study interval 